\title{
Device Remains Implanted
}

National Cancer Institute

\section{Source}

National Cancer Institute. Device Remains Implanted. NCI Thesaurus. Code C118639.

An appliance or mechanism that continues to be implanted. 